\title{
Lack of evidence of paratuberculosis in wild canids from Southwestern Europe
}

\author{
Raquel Sobrino • O. Aurtenetxe • Tania Carta $\cdot$ L. Mamian • X. Gerrikagoitia • \\ A. Balseiro • A. Oleaga • I. A. Sevilla • M. Barral • J. M. Garrido $\cdot$ Christian Gortazar
}

Received: 23 August 2010 /Revised: 16 December 2010 / Accepted: 19 December 2010 / Published online: 7 January 2011

(C) Springer-Verlag 2011

\begin{abstract}
Wild carnivores are at the top of the trophic chain. They are predators and carrion consumers, and thus, prone to come in contact with disease agents contaminating the environment or infecting live or dead animals. We hypothesized that wild canids could be used as sentinels for the detection of regions with higher Mycobacterium avium paratuberculosis (MAP) prevalence in wild and domestic animals. To test this hypothesis, we set up an ELISA to test 262 wolf (Canis lupus) and fox (Vulpes vulpes) sera for MAP-specific antibodies and processed a subset of samples for culture $(n=$ 61), MAP-specific PCR (15) and histopathology (14). In wolves, the optical density (OD) values in the ELISA were continuously distributed. Ten fox sera (4\%) had OD readings of over twice the mean, suggesting contact with mycobacteria. However, all samples tested by PCR were negative for
\end{abstract}

Communicated by M. Artois

R. Sobrino $\cdot$ T. Carta $\cdot$ L. Mamian · A. Oleaga $\cdot$ C. Gortazar $(\bowtie)$ Instituto de Investigación en Recursos Cinegéticos IREC (CSIC-UCLM-JCCM),

Ronda de Toledo s.n.,

13071 Ciudad Real, Spain

e-mail: Christian.Gortazar@uclm.es

O. Aurtenetxe $\cdot$ X. Gerrikagoitia $\cdot$ I. A. Sevilla $\cdot$ M. Barral $\cdot$

J. M. Garrido

Animal Health Department,

NEIKER-Tecnalia,

48160 Derio Bizkaia, Spain

R. Sobrino

Department of Animal Production, Epidemiology \& Ecology,

University of Turin,

10095 Grugliasco, Italy

A. Balseiro $\cdot$ A. Oleaga

SERIDA, Centro de Biotecnología Animal,

33394 Deva-Gijón (Asturias), Spain both IS900 and ISMAP02 sequences, and samples cultured for MAP yielded no growth. No visible paratuberculosis or tuberculosis-compatible lesions were recorded. On histopathological examination, no lesions compatible with mycobacterial diseases were observed. These results suggest that wild canids show little or no evidence of paratuberculosis and are unlikely to be useful sentinels for the detection of MAP in Southwestern Europe.

Keywords Carnivore $\cdot$ Johne's disease $\cdot$ Mycobacterium avium paratuberculosis $\cdot$ Mycobacterium bovis $\cdot$ Wildlife sentinel

\section{Introduction}

Animals may serve as indicators of human health threats in the environment. Examples include the emergence of zoonotic diseases in wildlife populations, concurrent with a novel outbreak of disease in humans, such as West Nile virus, SARS, and avian influenza (Scotch et al. 2009). Wild animals can also act as indicators of diseases circulating among domestic animals or other wildlife. For example, white-tailed deer (Odocoileus virginianus) have been used to detect Anaplasma phagocytophilum (Rainwater et al. 2006) and Ehrlichia chaffeensis (Yabsley et al. 2003), and feral pigs (Sus scrofa) to detect bovine tuberculosis (Nugent et al. 2002). These indicator species are known as "sentinels".

Wild carnivores are at the top of the trophic chain. They are predators and carrion consumers, and thus, prone to come in contact with disease agents contaminating the environment or infecting live or dead animals (Anderson et al. 2007; Sobrino et al. 2007); therefore, they could act as sentinels. For example, sea otters (Enhydra lutris nereis) can act as sentinels to detect Toxoplasma gondii contamination in 
coastal environments (Conrad et al. 2005) and coyotes (Canis latrans) have been used to detect Mycobacterium bovis circulation in wildlife and domestic animals. In Michigan, focusing surveillance on coyotes, rather than on white-tailed deer increased the detection of M. bovis by $40 \%$ (VerCauteren et al. 2008).

The Iberian Peninsula is one of the last strongholds of the wolf(Canis lupus) in Europe, with an estimated population of 2,500 individuals, mainly in the north-west of the peninsula (Blanco 1998). Wolves in Spain depend largely on domestic and wild ungulates as a food source (Cuesta et al. 1991; Barja 2009). Red foxes (Vulpes vulpes) are ubiquitous, anthropophilic generalists, with a species abundance ranging from 0.5 to 10 foxes per square kilometer (Gortázar 1997). They are also a game species, which makes sample collection relatively easy. In Spain, the fox behaves as a facultative predator, feeding on rabbits (Oryctolagus cuniculus) when they are abundant and shifting to other prey (including carrion of wild and domestic ungulates) when rabbits are scarce (Delibes-Mateos et al. 2008).

Paratuberculosis is chronic enteritis that mainly occurs in wild and domestic ruminants, caused by Mycobacterium avium paratuberculosis (MAP), a member of the Mycobacterium avium complex (Thorel et al. 1990). MAP also occurs in many non-ruminant mammals and in several bird species. However, the significance of MAP in non-ruminant wildlife is largely unknown (Daniels et al. 2003). Among carnivores, sporadic isolation of MAP has been reported in foxes, Eurasian badgers (Meles meles), stoats (Mustela erminea), and weasels (Mustela nivalis) in Scotland (Beard et al. 2001), and from a red fox in Greece (Florou et al. 2008). In Spain, MAP is widespread among both domestic and wild ruminants (Garrido 2001; Falconi et al. 2010) and has also been recorded in wild rabbits (the authors, submitted). Among red deer (Cervus elaphus), for instance, 30\% antibody prevalence was reported, and contact with cattle was identified as a risk factor (Reyes-García et al. 2008).

Hence, the available information suggests that wild carnivores could be useful in surveillance schemes for mycobacteria, including MAP. We hypothesized that foxes (and wolves to a lesser extent due to their limited availability) could be used as sentinels to identify regions with higher MAP prevalence among domestic and wild ruminants. To test this hypothesis, we sampled wild canids from Spain, set up an ELISA to test for MAP-specific antibodies and processed a subset of samples for culture, MAP-specific PCR, and histopathology.

\section{Material and methods}

In the period of 2004-2009, samples were collected from 24 wolf and 285 fox carcasses from different Spanish regions (Fig. 1). All animals had been legally obtained as road kills (wolves and foxes) or from hunters (foxes only), and were frozen at $-20^{\circ} \mathrm{C}$ until necropsy. Age class, which was assigned as yearling $(<1$ year) or adult $(>1$ year) was determined by tooth eruption and the degree of tooth wear (Sáenz de Buruaga et al. 2001). Age or sex was not known for 36 foxes and 18 wolves. In the laboratory, carcasses were thawed and examined at necropsy for visible lesions. Separate, clean instruments were used for each animal to reduce the risk of crosscontamination. Serum samples were obtained by centrifugation of thoracic blood and stored at $-20^{\circ} \mathrm{C}$ until their analysis. Samples of ileocecal valve (ICV) and mesenteric lymph nodes $(\mathrm{mLN})$ were transferred to clean containers and frozen in duplicate at $-20^{\circ} \mathrm{C}$ until analysis. Table 1 presents the number of samples processed for histopathology, ELISA, PCR and culture, respectively.

The ELISA test to detect antibodies against MAP was performed adapting protocols reported previously for ruminants (Garrido 2001; Sevilla et al. 2007; Reyes-García et al. 2008). Briefly, high adsorption capacity Costar polystyrene microtiter plates (Cultek, Madrid, Spain) were coated with $50 \mu \mathrm{l} /$ well of $0.02 \mathrm{mg} / \mathrm{ml}$ paratuberculosis protoplasmatic antigen 3 (PPA-3) diluted in carbonate/bicarbonate buffer (Sigma, Madrid, Spain). The serum samples were adsorbed $(1: 1, v / v)$ with a saline suspension of Mycobacterium phlei ( $5 \mathrm{~g} / \mathrm{l})$ (Allied Monitor, Inc., Fayette, MO, USA) and left at $4^{\circ} \mathrm{C}$ overnight to remove nonspecific anti-Mycobacterium spp. antibodies (Milner et al. 1987). Thereafter, the plates were washed once with a washing solution (PBS containing $0.05 \%$ Tween 20 ) and blocked with $200 \mu 1 /$ well of blocking solution $(5 \%$ nonfat dried milk in PBS containing $0.05 \%$ Tween 20). After a 1-h incubation period at room temperature, sera diluted 1:20 $(v / v)$ in PBS solution were added into wells of the antigen-coated plate. The plates were incubated at $37^{\circ} \mathrm{C}$ for $1 \mathrm{~h}$, before being washed four times with the washing solution. Anti-dog IgG peroxidase antibody produced in rabbits was used as conjugate (Sigma, $0.002 \mathrm{mg} / \mathrm{ml}$ in blocking solution) and incubated at $37^{\circ} \mathrm{C}$ for $1 \mathrm{~h}$. After four washes with washing solution, $200 \mu \mathrm{l} /$ well of substrate solution (Fast OPD, Sigma) were added. Approximately $20 \mathrm{~min}$ later, the reaction was stopped with $50 \mu \mathrm{l} /$ well of $\mathrm{H}_{2} \mathrm{SO}_{4} 3 \mathrm{~N}$ and optical density (OD) was measured in a spectrophotometer at $450 \mathrm{~nm}$. Since no positive controls were available, we used $2 \times$ the mean OD as a conservative arbitrary cutoff (see Fig. 2).

A modified version of the Adiapure ${ }^{\circledR}$ kit (Adiagene, Saint Brieuc, France) was used for DNA extraction from tissue samples (ICV and $\mathrm{mLN}$ ). A sample of $2.5 \mathrm{~g}$ was weighed in a Stomacher blending bag with filter and $10 \mathrm{ml}$ of sterile water was added. After homogenization in a Stomacher lab blender, $300 \mu \mathrm{l}$ of filtered liquid was transferred into 2-ml microcentrifuge tubes containing 
Fig. 1 Map of continental Spain showing the sample size by site and species (foxes, Vulpes vulpes, in gray; and wolves, Canis lupus, in white)

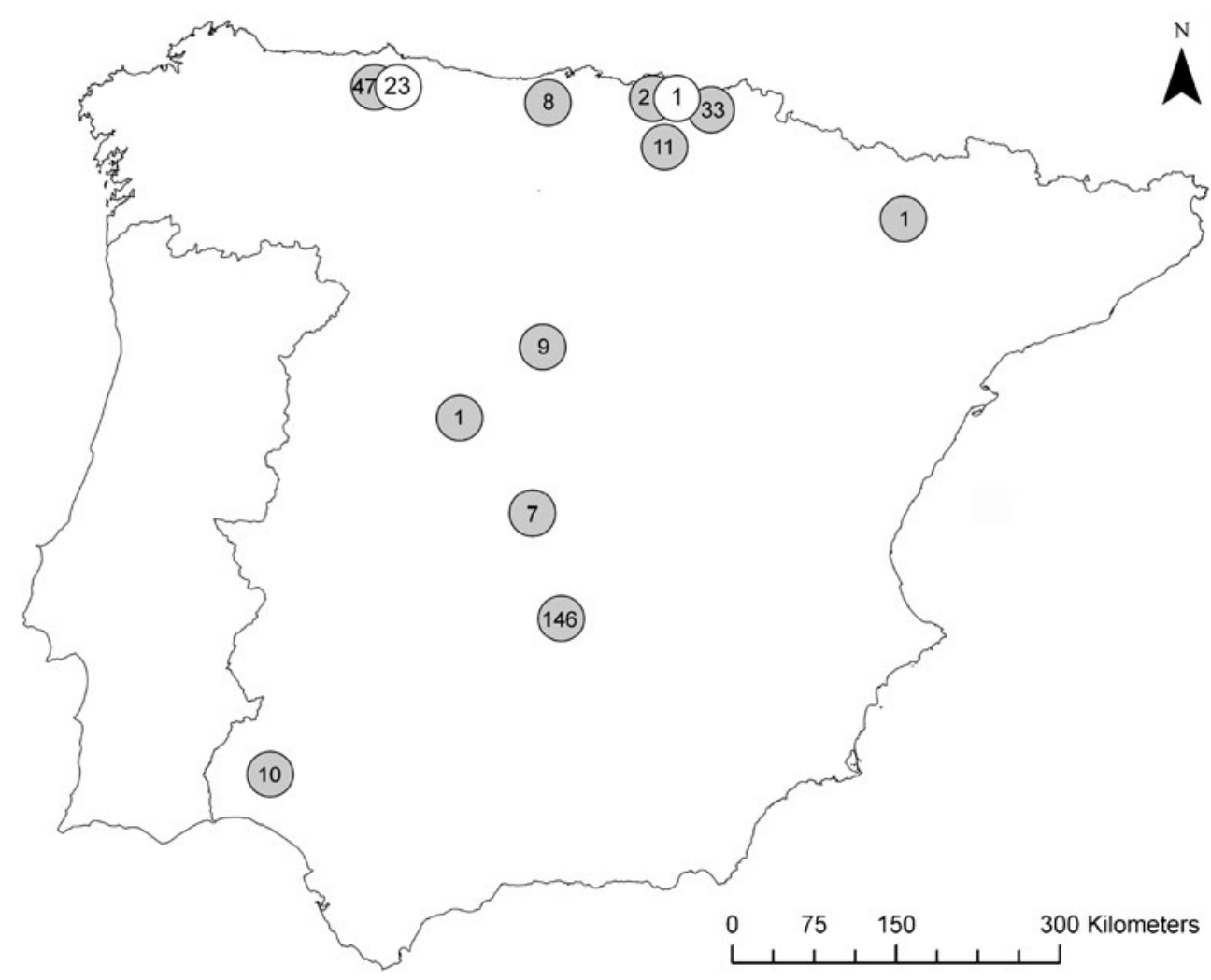

$300 \mathrm{mg}$ of glass beads. Then $300 \mu \mathrm{l}$ of L1 buffer (Adiapure) was added, and the tubes were shaken three times at 4,000 rpm for $45 \mathrm{~s}$ in a Precess 48 homogenizer (Biorad, Hemel Hempstead, Hertfordshire, UK). After mechanical disruption, samples were centrifuged at $7,500 \mathrm{~g}$ for $5 \mathrm{~min}$. We transferred $300 \mu \mathrm{l}$ of supernatant into a $1.5-\mathrm{ml}$ microcentrifuge tube containing $20 \mu \mathrm{l}$ of L2 reagent (Adiapure) and the mixture was incubated at $70^{\circ} \mathrm{C}$ for $10 \mathrm{~min}$. An additional incubation at $95^{\circ} \mathrm{C}$ for $15 \mathrm{~min}$ was carried out. Samples were shortly centrifuged at full speed to collect all the content at the bottom of the tube, and $300 \mu \mathrm{l}$ of this mixture was transferred into an F1 plate (Adiapure) well. Subsequent steps were performed as indicated by the manufacturer of the kit.

DNA extracts were used in a triplex real-time PCR targeting IS900 (Herthnek et al. 2006) and ISMAP02

Table 1 Number of red fox (Vulpes vulpes) and wolf (Canis lupus) samples analyzed by each technique for the detection of MAP antibodies by ELISA, MAP DNA by PCR, MAP growth in culture, and paratuberculosis-compatible lesions by histopathology

\begin{tabular}{lllll}
\hline \multicolumn{5}{c}{ Samples tested } \\
\hline Host species & ELISA & PCR & Culture & Histopathology \\
Red fox & 239 & 14 & 56 & 13 \\
Wolf & 23 & 1 & 5 & 1 \\
Total & 262 & 15 & 61 & 14 \\
\hline
\end{tabular}
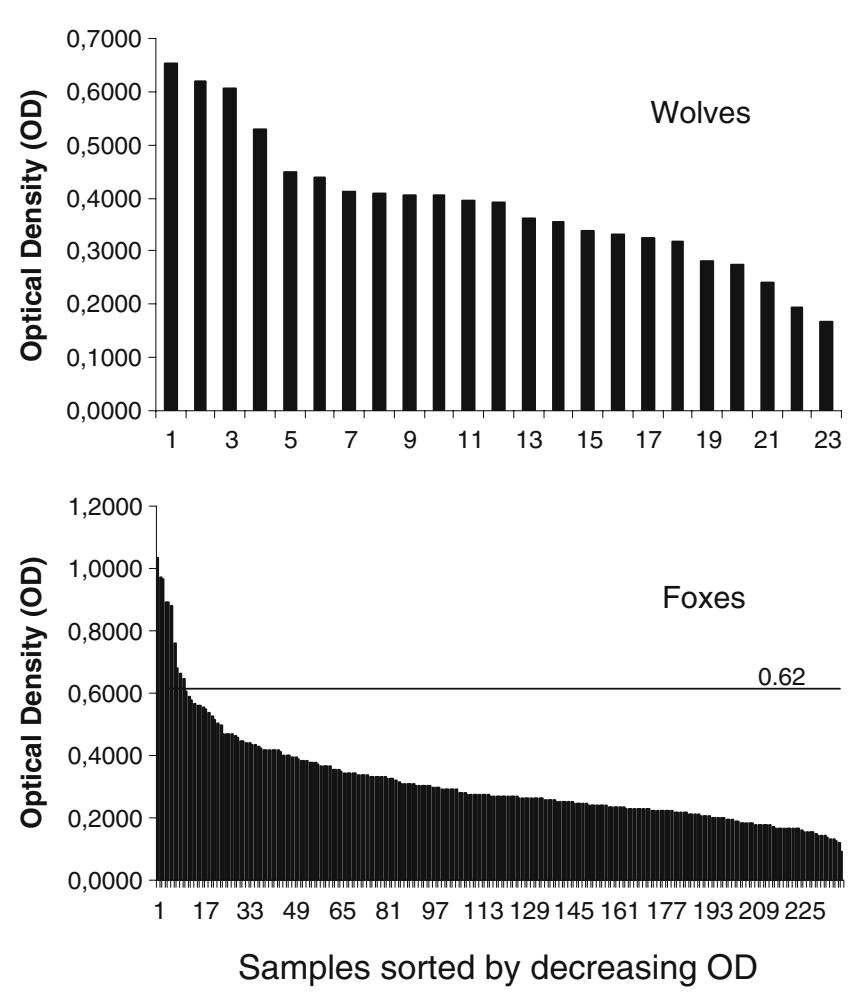

Fig. 2 Distribution of OD values for red fox sera $(n=239)$ and wolf sera $(n=23)$ in the antigen-adsorbed ELISA. Plates were coated with PPA3. The solid line in the fox graph represents twice the mean OD, showing that ten samples had ODs above this arbitrary cutoff 
sequences of MAP and an internal amplification control (IAC) to rule out inhibition of the reaction (Sevilla et al., submitted). The 50- $\mu$ l PCR mixture contained $5 \mu$ l of template DNA, $1 \times$ TaqMan Universal MasterMix (Applied Biosystems, CA), $0.4 \mu \mathrm{M}$ (each) of primers co-amplifying ISMAP02 and the IAC, $0.3 \mu \mathrm{M}$ (each) of IS900 primers, $0.2 \mu \mathrm{M}$ (each) of ISMAP02, IAC and IS900 probes and $2 \mu \mathrm{l}$ of IAC template DNA (Sevilla et al., submitted). Amplification was carried out in an Applied Biosystems 7500 Real-Time PCR System under the following standard conditions: 1 cycle at $95^{\circ} \mathrm{C}$ for $10 \mathrm{~min}$ and 45 cycles with two steps of $95^{\circ} \mathrm{C}$ for $15 \mathrm{~s}$ and $60^{\circ} \mathrm{C}$ for $1 \mathrm{~min}$. The performance of the PCR was monitored using a negative and a positive DNA control (ATCC 19698 reference strain).

For each culture, $2 \mathrm{~g}$ of a pool of similar volumes of ileocecal valve and mesenteric lymph node of each animal were processed. Samples were homogenized and decontaminated with $38 \mathrm{ml}$ of a solution $(0.75 \%)$ of hexadecilpiridinium chloride (HPC; Aduriz et al. 1995). Three drops of the homogenate were inoculated on homemade Herrold's Egg Yolk medium (HEYM) and Löwestein-Jensen medium (LJ), both supplemented with mycobactin J (Allied Monitor) and Middlebrook 7H11 supplemented with 1\% Middlebrook OADC Enrichment (Becton, Dickinson and Company, MD, USA) (Sevilla et al. 2007). Tubes were incubated at $37^{\circ} \mathrm{C}$ and inspected monthly. They were considered negative if no bacterial growth was observed after 20 weeks.

For histopathological studies, samples (retropharyngeal and submandibular LN, lungs, heart, spleen, kidney, ICV, and $\mathrm{mLN}$ ) from 13 animals were fixed in $10 \%$ neutral buffered formalin, dehydrated in graded ethanol solutions, embedded in paraffin wax, sectioned at 4- $\mu \mathrm{m}$ thickness and stained with $\mathrm{H} \& \mathrm{E}$ and Ziehl-Neelsen (ZN) for acid-fast bacteria (AFB).

\section{Results}

Figure 2 presents the OD of all wild canid sera tested for antibodies against PPA3. In wolves, the OD values in the ELISA were not discrete and were continuously distributed. The mean OD for wolf sera was 0.39 , and no OD was higher than twice this value. In fox sera, the mean OD was 0.31 and 10 samples $(4.18 \%)$ had OD readings of over twice this mean. These included 9 of 156 sera from Southern Spain and 1 of 119 from Northern Spain (Fisher's test, $p=0.032$ ). The red fox sample with the highest response had an OD of 1.03 .

All samples tested by PCR were negative for both IS900 and ISMAP02 sequences, and all controls yielded the expected result. Inhibition of the reaction was ruled out in all assays by the positive signal observed for the IAC probe. Tissue samples cultured for MAP yielded no isolation, and no bacterial growth was observed.

No visible paratuberculosis or bTB-compatible lesions were recorded during the necropsies. On histopathological examination, no lesions compatible with mycobacterial diseases were observed in the tissues studied. AFB was not demonstrated by $\mathrm{ZN}$ stain.

\section{Discussion}

Results reported herein led us to reject the initial hypothesis that wild canids could be used as paratuberculosis sentinels in a zone where the prevalence of paratuberculosis in wild ruminants is high (Reyes-García et al. 2008). This contrasts with data from Wisconsin (USA), where MAP-specific DNA was detected in a high proportion of scavenging mammals, including coyotes and red foxes (Anderson et al. 2007).

In the absence of PCR confirmation or MAP isolation by culture, the interpretation of ELISA results is difficult. Wolves were sampled in regions of Northern Spain with very low bTB prevalence in cattle and almost no wildlife TB (Gortázar et al. in press). No wolf serum yielded high ODs, suggesting no contact with MAP or cross-reacting mycobacteria. In the foxes, a few sera (4\%) had relatively high ODs, suggesting some contact with mycobacteria. These occurred mainly in two bTB endemic areas of Southern Spain, suggesting that cross-reactions after contact with $M$. bovis could have influenced the ELISA results. Serological cross-reactions of $M$. bovis, and MAP have often been reported (e.g., Buddle et al. 2010). Alternatively, rabbits are more abundant in Southern Spain and consumption of MAP-infected rabbits could also explain the few antibody-positive fox sera.

The absence of mycobacterial isolations was no surprise, considering the low sensitivity of this technique (Anderson et al. 2007). In contrast, the lack of PCR detection of MAP-specific DNA is interesting. The methods used for the carnivores in this survey have a high sensitivity (Herthnek et al. 2006). As was discussed earlier, both wolves and foxes include significant portions of wild ruminants and rabbits in their diet. Thus, exposure to MAP was expected but not confirmed. The contrast with the high-PCR positivity recorded among carnivores in Wisconsin (Anderson et al. 2007) may be explained by the small number of PCR-tested samples in the present study. Alternatively, it might be due to differences in specificity or sensitivity between the PCR protocols used.

Since canids only rarely develop lesions when they have a generalized M. bovis infection (Millan et al. 2008), the lack of paratuberculosis and bTB-compatible lesions was not a surprising finding in this study. However, this lack of 
visible lesions in a large sample of wild canids, along with the absence of microscopic lesions in the studied subsample, adds to the view that wild canids play no relevant role in the epidemiology of mycobacterial diseases in Southwestern Europe. This finding, in addition to the absence of MAP detection by culture and PCR, suggests that wild canids show little or no evidence of paratuberculosis and are unlikely to be useful sentinels for the detection of MAP in Southwestern Europe. However, studies on other situations or even experimental studies that would be needed before definitive conclusions on the role of canids in MAP epidemiology can be drawn.

Acknowledgments We thank Paqui Talavera, Joaquín Vicente, Oscar Rodriguez, and many colleagues for their help with the field and laboratory work and Pelayo Acevedo for his help with the figures. This study is a contribution to grant AGL2008-03875 Plan Nacional MCINN and FEDER, European Research Project 212414 "Strategies for the Eradication of Bovine Tuberculosis, Tb-Step", and the agreements with Ministerio de Medio Ambiente y Medio Rural y Marino, Principado de Asturias, and Castilla-La Mancha. R. Sobrino had a grant from Castilla-La Mancha. The experiments and procedures included in this study comply with the national and European laws. Sponsors had no role in the study design, in the collection, analysis and interpretation of data; in the writing of the manuscript; and in the decision to submit the manuscript for publication. Lucy Anderson kindly reviewed the English language and two anonymous reviewers provided constructive comments that helped to improve the original manuscript.

\section{References}

Aduriz JJ, Juste RA, Cortabarría N (1995) Lack of mycobactin dependence of mycobacteria isolated on Middlebrook $7 \mathrm{H} 11$ from clinical cases of ovine paratuberculosis. Vet Microbiol 45:211217

Anderson JL, Meece JK, Koziczkowski JJ, Clark DL, Radcliff RP, Nolden CA, Samuel MD, Ellingson JLE (2007) Mycobacterium avium subsp. paratuberculosis in scavenging mammals in Wisconsin. J Wildl Dis 43:302-308

Barja I (2009) Prey and prey-age preference by the Iberian wolf Canis lupus signatus in a multiple-prey ecosystem. Wildl Biol 15:147154

Beard PM, Daniels MJ, Henderson D, Pirie A, Rudge K, Buxton D, Rhind S, Greig A, Hutchings MR, McKendrick I, Stevenson K, Sharp JM (2001) Paratuberculosis infection of nonruminant wildlife in Scotland. J Clin Microbiol 39:1517-1521

Blanco JC (1998) Mamíferos de España. Guía de campo. Volúmen 1. Insectívoros, quirópteros, primates y carnívoros de la Península Ibérica, Baleares y Canarias. Planeta, Barcelona

Buddle BM, Wilson T, Denis M, Greenwald R, Esfandiari J, Lyashchenko KP, Liggett S, Mackintosh CG (2010) Sensitivity, specificity, and confounding factors of novel serological tests used for the rapid diagnosis of bovine tuberculosis in farmed red deer (Cervus elaphus). Clin Vaccine Immunol 17:626-630

Conrad PA, Miller MA, Kreuder C, James ER, Mazet J, Dabritz H, Jessup DA, Gulland F, Grigg ME (2005) Transmission of Toxoplasma: clues from the study of sea otters as sentinels of Toxoplasma gondii flow into the marine environment. Int $\mathrm{J}$ Parasitol 35:1155-1168
Cuesta L, Barcena F, Palacios F, Reig S (1991) The trophic ecology of the Iberian wolf (Canis-lupus-signatus Cabrera, 1907) - a new analysis of stomachs data. Mammalia 55:239-254

Daniels MJ, Hutchings MR, Beard PM, Henderson D, Greig A, Stevenson K, Sharp JM (2003) Do non-ruminant wildlife pose a risk of paratuberculosis to domestic livestock and vice versa in Scotland? J Wildl Dis 39:10-15

Delibes-Mateos M, de Simon JF, Villafuerte R, Ferreras P (2008) Feeding responses of the red fox (Vulpes vulpes) to different wild rabbit (Oryctolagus cuniculus) densities: a regional approach. Eur J Wildl Res 54:71-78

Falconi C, Oleaga A, Lopez-Olvera JR, Casais R, Prieto M, Gortazar C (2010) Prevalence of antibodies against selected agents shared between Cantabrian chamois (Rupicapra pyrenaica parva) and domestic goats. Eur J Wildl Res 56:319-325

Florou M, Leontides FM, Kostoulas L, Billinis C, Sofia M, Kyriazakis I, Lykotrafitis F (2008) Isolation of Mycobacterium avium subspecies paratuberculosis from non-ruminant wildlife living in the sheds and on the pastures of Greek sheep and goats. Epidemiol Infect 136:644-652

Garrido JM (2001) Puesta a punto de técnicas de PCR en heces y de ELISA para el diagnóstico de la paratuberculosis. Estudio de prevalencia en ganado bovino. PhD Thesis, Universidad de Zaragoza, Zaragoza

Gortázar C (1997) Ecología y patología del zorro (Vulpes vulpes) en el valle medio del Ebro. PhD Thesis, Universidad de Zaragoza, Zaragoza

Gortázar C, Vicente J, Boadella M, Ballesteros C, Galindo RC, Garrido JM, Aranaz A, de la Fuente J (2011) Progress in the control of bovine tuberculosis in Spanish wildlife. Vet Microbiol (in press)

Herthnek D, Englund S, Willemsen PTJ, Bolske G (2006) Sensitive detection of Myobacterium avium subsp paratuberculosis in bovine semen by real-time PCR. J Appl Microbiol 100:10951102

Millan J, Jimenez MA, Viota M, Candela MG, Pena L, Leon-Vizcaino L (2008) Disseminated bovine tuberculosis in a wild red fox (Vulpes vulpes) in Southern Spain. J Wildl Dis 44:701-706

Milner AR, Lepper AWD, Symonds WN, Gruner E (1987) Analysis by ELISA and Western blotting of antibody reactivities in cattle infected with Mycobacterium paratuberculosis after absorption of serum with $M$. phlei. Res Vet Sci 42:140-144

Nugent G, Whitford J, Young N (2002) Use of released pigs as sentinels for Mycobacterium bovis. J Wildl Dis 38:665-677

Rainwater KK, Ijdo J, Capuano A, Gilchrist MJ, Grill JS (2006) Serosurveillance for Anaplasma phagocytophilum antibodies in white-tailed deer (Odocoileus virginianus) in Iowa, USA. Vector Borne Zoonotic Dis 6:275-282

Reyes-García R, Pérez-de-la-Lastra JM, Vicente J, Ruiz-Fons F, Garrido JM, Gortázar C (2008) Large-scale ELISA testing of Spanish red deer for paratuberculosis. Vet Immunol Immunopathol 124:75-81

Sáenz de Buruaga M, Lucio AJ, Purroy FJ (2001) Reconocimiento de sexo y edad en especies cinegéticas. Edilesa, León, Spain, pp 20 23

Scotch M, Odofin L, Rabinowitz P (2009) Linkages between animal and human health sentinel data. BMC Vet Res 5:15

Sevilla I, Garrido JM, Geijo M, Juste RA (2007) Pulsed-field gel electrophoresis profile homogeneity of Mycobacterium avium subsp. paratuberculosis isolates from cattle and heterogeneity of those from sheep and goats. BMC Microbiol 7:18

Sobrino R, Cabezón O, Millán J, Pabón M, Arnal MC, Luco DF, Gortázar C, Dubey JP, Almeria S (2007) Seroprevalence of Toxoplasma gondii antibodies in wild carnivores from Spain. Vet Parasitol 148:187-192

Thorel MF, Krichevsky M, Levy-Frebault VV (1990) Numerical taxonomy of mycobactin-dependent mycobacteria, emended 
description of Mycobacterium avium, and description of Mycobacterium avium subsp. avium subsp. nov., Mycobacterium avium subsp. paratuberculosis subsp. nov., and Mycobacterium avium subsp. silvaticum subsp. nov. Int J Syst Bacteriol 40:254260

VerCauteren K, Atwood TC, DeLiberto TJ, Smith HJ, Stevenson JS, Thomsen BV, Gidlewski T, Payeur J (2008) Sentinel-based surveillance of coyotes to detect bovine tuberculosis, Michigan. Emerg Infect Dis 14:1862-1869

Yabsley MJ, Dugan VG, Stallknecht DE, Litle SE, Lockhart JM, Dawson JE, Davidson WR (2003) Evaluation of a prototype Ehrlichia chaffeensis surveillance system using white-tailed deer (Odocoileus virginianus) as natural sentinels. Vector Borne Zoonotic Dis 3:195-207 